\title{
Genotoxicity of Silver Nanoparticles in Vicia faba: A Pilot Study on the Environmental Monitoring of Nanoparticles
}

\author{
Anita K. Patlolla $^{1, *}$, Ashley Berry ${ }^{1,2}$, LaBethani May ${ }^{1,2,3}$ and Paul B. Tchounwou ${ }^{1}$ \\ 1 Molecular Toxicology Research Laboratory, NIH-RCMI Center for Environmental Health, College \\ of Science Engineering and Technology, Jackson State University, Jackson, MS 39217, USA; \\ E-Mails: ashleyberry@gmail.com (A.B.); labeth@yahoo.com (L.M.); \\ paul.b.tchounwou@jsums.edu (P.B.T.) \\ 2 Department of Biology, Jackson State University, Jackson, MS 39217, USA \\ 3 Murray High School Student-SEPA Program, Jackson State University, Jackson, MS 39217, USA \\ * Author to whom correspondence should be addressed; E-Mail: anita.k.patlolla@jsums.edu; \\ Tel.: +1-601-979-0210; Fax: +1-601-979-5853.
}

Received: 16 November 2011; in revised form: 12 December 2011 / Accepted: 13 December 2011 / Published: 4 May 2012

\begin{abstract}
The use of silver nanoparticles (AgNPs) in commercial products has increased significantly in recent years. Although there have been some attempts to determine the toxic effects of AgNPs in mammalian and human cell-lines, there is little information on plants which play a vital role in ecosystems. The study reports the use of Vicia faba root-tip meristem to investigate the genotoxicity of AgNPs under modified GENE-TOX test conditions. The root tip cells of $V$. faba were treated with four different concentrations of engineered AgNPs dispersion to study toxicological endpoints such as mitotic index (MI), chromosomal aberrations (CA) and micronucleus induction (MN). For each concentration, five sets of microscopy observations were carried out. The results demonstrated that AgNPs exposure significantly increased $(p<0.05)$ the number of chromosomal aberrations, micronuclei, and decreased the MI in exposed groups compared to control. From this study we infer that AgNPs might have penetrated the plant system and may have impaired mitosis causing CA and MN. The results of this study demonstrate that AgNPs are genotoxic to plant cells. Since plant assays have been integrated as a genotoxicity component in risk assessment for detection of environmental mutagens, they should be given full consideration when evaluating the overall toxicological impact of the nanoparticles in the environment.
\end{abstract}


Keywords: silver nanoparticles; chromosomal aberrations; mitotic index; Vicia faba; genotoxicity; micronucleus

\section{Introduction}

Nanomaterials are part of an industrial revolution to develop lightweight but strong materials for a variety of purposes [1]. Due to the novel physical and chemical properties of nanoscale materials, nanomaterials have been used to create new consumer products as well as applications for life sciences and biotechnology. Chemically, the nanoparticles are very diverse. It is estimated that of all the nanomaterials used in consumer products, silver nanoparticles (AgNPs) currently have the highest degree of commercialization [2], so they are more likely to be exposed to humans and to the environment at large. The toxic effects of nanoparticles have been evaluated in a variety of studies; however the potential health and environmental impacts on plants have yet to be thoroughly examined. Their uniquely small size and large surface area is a key indicator of toxicity which allows them to translocate when inhaled [3]. Most recently, nanomaterials such as single- and multi-walled nanotubes, nanofibers, fullerene derivatives, quantum dots, and metal oxide nanoparticles have received much attention due to their toxicity on human cells, bacteria, and rodents [4-11]. With increasing interest in its potential toxicity, the adverse effects of engineered nanomaterials are intensively being investigated. To date, the studies that report on toxic effects of AgNPs either in vivo [12-14] or in vitro [15-18] further provide data indicating adverse health effects of cells exposed to AgNPs. AgNPs have also been shown to be genotoxic in plant cells [19]. Moreover, the toxicity of AgNPs has been observed to be mediated through oxidative stress or the generation of reactive oxygen species (ROS) as revealed by several studies [20,21]. Studies on potential toxicity of nanoparticles to ecological terrestrial test species are still lacking [22]. The studies on both positive and negative effects of nanoparticles on higher plants are very few. Lu et al. [23] showed that nanoscale $\mathrm{SiO}_{2}$ and $\mathrm{TiO}_{2}$ enhanced nitrate reductase activity in soybean, and apparently hastened its germination and growth. Several studies reported that $\mathrm{Nano}-\mathrm{TiO}_{2}$ promoted photosynthesis and nitrogen metabolism, and improved growth of spinach [24-27].

Exposure to nanoparticles can occur via water, food, cosmetics, drugs, and drug delivery devices, and can lead to a wide variety of toxicological effects [14]. Silver nanoparticles (AgNPs) have been rapidly employed in the manufacturing of many products such as healthcare items, room-sprays, pipelines, and washing machines due to its long-standing antibacterial properties [28,29]. It has been termed as a broad-spectrum biocide due to its ability to target a wide array of bacteria [30]. Silver impregnated catheters and wound dressings are used in therapeutic applications. In spite of the wide usage of AgNP in wound dressings, which can cause easy entry into the cells, very few reports on the toxicity of AgNPs are available. Several recently published reports state that despite the many promises of AgNPs, there are many unknown risks which have not been properly assessed prior to their high industrialized usage. Silver (Ag) is classified as an environmental hazard by the EPA because it is more toxic to aquatic plants and animals than any other metal except for mercury. Even if a nanoparticle itself is not especially toxic, silver nanoparticles increase the effectiveness of delivering 
toxic silver ions to locations where they can cause toxicity. In the near future there is a risk of enhanced bioavailability of the nanoparticles in the environment [13].

The mitotic root meristems of Vicia faba (broad beans) have been the pioneer cytogenetic materials for the detection of genotoxicity study of environmental pollutants. Based upon USEPA Gene-Tox Program chromosome aberration frequencies in the root-tips of $V$. faba have been used as indicators of genotoxicity. Plant assays have been integrated as a genotoxicity component in risk assessment for detection of environmental mutagens because of the simple, quick, inexpensive, efficient and reliable characters. The $V$. faba root tip chromosomal aberration assay is an established plant bioassay validated by the International Programme on Chemical Safety (IPCS, WHO) and the United Nations Environment Programme (UNEP) as an efficient and standard test for the chemical screening and in situ monitoring for genotoxicity of environmental substances. $V$. faba has been used for evaluating chromosomal aberrations since the 1920s [31-34].

Although AgNPs have been the subject of important toxicological research, there exists a lack of appropriate plant model for genotoxicity assessment. There is also a scarcity of scientific data describing the dose-response relationship with respect to their cytogenetic toxicity in plant systems. The reports from few previous studies have advanced our knowledge of toxicological impact of several types of nanomaterials. There are still many unresolved issues and challenges concerning the biological effects of nanoparticles. Therefore, the present study is designed to investigate clastogenic/genotoxic impacts of silver nanoparticles on $V$. faba.

\section{Materials and Methods}

\subsection{Nanoparticles}

Silver nanoparticles (AgNPs, Figure 1) were obtained from Ocean Nanotech LLC. (Fayetteville, AK, USA). The physical characteristics of the particles according to manufacturers' data are $60 \mathrm{~nm}$ diameter size, $99.5 \%$ purity (trace metal basis), $400.0 \mathrm{~m}^{2} / \mathrm{g}$ surface area and $10.59 \mathrm{~g} / \mathrm{mL}$ density.

\subsection{Test System and Treatment}

The Ag-NPs were suspended directly in deionized water (DI-water) and dispersed by ultrasonic vibration $(100 \mathrm{~W}, 30 \mathrm{KHz})$ for $30 \mathrm{~min}$ to produce four different concentrations at $12.5 \mathrm{mg} / \mathrm{L}, 25 \mathrm{mg} / \mathrm{L}$, $50 \mathrm{mg} / \mathrm{L}$ and $100 \mathrm{mg} / \mathrm{L}$.

\subsection{Plant as Test Material-Vicia faba}

Several plant bioassays have been used for detecting mutagens and clastogens for the past 40 years. As a cytogenetic, material $V$. faba has the advantage of having six pairs of relatively large chromosomes that is excellent for assessing chromosomal aberrations. The $V$. faba root tip chromosomal aberration assay is an established plant bioassay by IPCS, WHO because of the simple, quick, inexpensive, efficient and reliable characters which can be utilized for in situ evaluation of the biological hazards of environmental pollution. 
Figure 1. Transmission electron microscope image of silver nanoparticles.

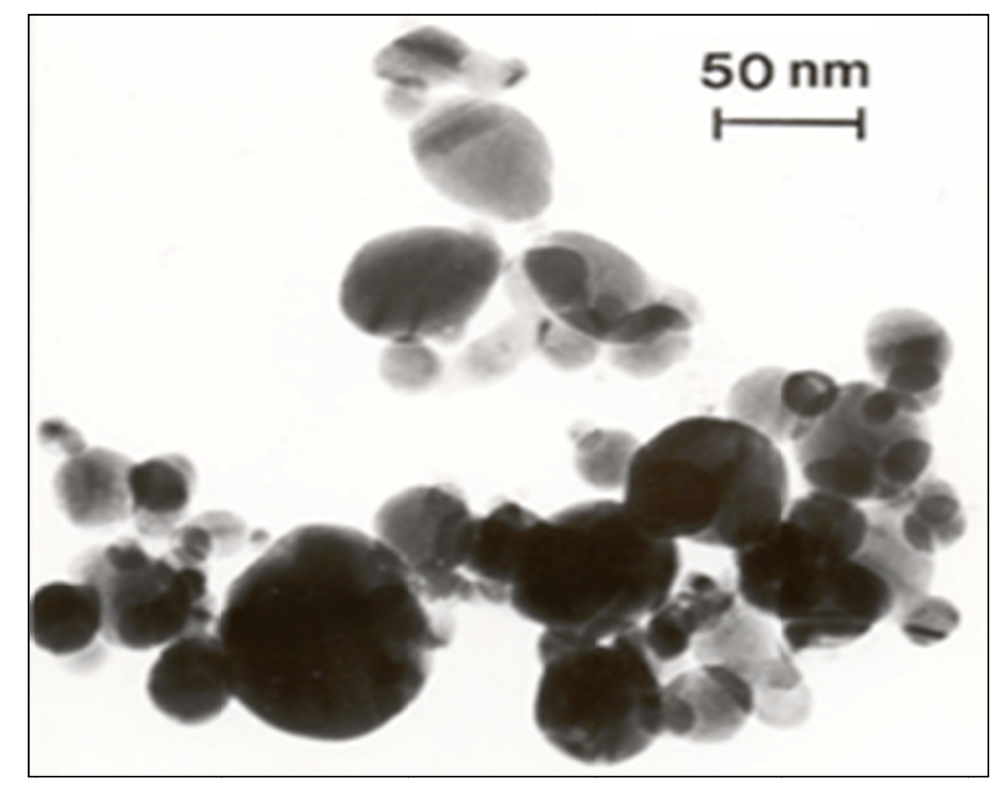

2.3.1. Storage of Seeds:

The $V$. faba (Broad beans) seeds are preferably stored in a refrigerator with a temperature of $4{ }^{\circ} \mathrm{C}$.

\subsubsection{Growing of Lateral Roots from Seeds}

V. faba (broad bean) seeds were purchased from Carolina Biologicals (Burlington, NC, USA). Before use, seeds were disinfected by a short immersion (3-10 $\mathrm{min}$ ) in a 5\% sodium hypochlorite solution, followed by rinsing thoroughly with 3-4 changes of distilled water. The $V$. faba seeds were soaked in de-chloride tap water at $25^{\circ} \mathrm{C}$ for 24 hour, and were then allowed to germinate between two layers of moistened cotton cloth in the dark for 3-5 days. When the primary root extended to $2-3 \mathrm{~cm}$ in length, the seed coat was peeled and the primary root tip was cut off $(2 \mathrm{~mm})$ in order to stimulate the emergence of secondary or lateral roots. The seedlings were suspended on water tanks and aerated constantly. The conditions for seedling growth were as follows $16 \mathrm{~h} \mathrm{light} / 8 \mathrm{~h}$ dark, $25^{\circ} \mathrm{C}$ and light intensity of 5,000-10,000 Lux. The water in the tank was kept fresh by changing every day. The water tank was well aerated and maintained constant temperature $\left(25^{\circ} \mathrm{C}\right)$ during growth period. After 4 days in the water tank, seedlings with lateral roots of $1-2 \mathrm{~cm}$ were used in the assay.

\subsubsection{Chromosomal Aberration Assay}

Four different concentrations of AgNPs $(12.5,25,50$ and $100 \mathrm{mg} / \mathrm{L})$ and a control were used in $V$. faba chromosomal assay. The treatments with the test chemical (AgNPs) were carried out at for $4 \mathrm{~h}$ in the dark, in vials containing at least $25 \mathrm{~mL}$ of the treatment solution. Each concentration had five replications. After the treatment the seedlings were kept in distilled water for $24 \mathrm{~h}$ as recovery period. The temperature during the growth period of the seedlings, as well as during treatment and recovery, was maintained at $25{ }^{\circ} \mathrm{C}$. Three hours prior to fixation the treated and the control root-tips were treated with $0.05 \%$ colchicine. 


\subsubsection{Fixation and Staining of Root Tips}

Roots tips were fixed in freshly prepared fixative containing three parts methanol and one part glacial acetic acid and kept at $4{ }^{\circ} \mathrm{C}$ until later use. For preparing the root tips smears, they were removed from the refrigerator and transferred to room temperature in distilled water for 5 minutes. The root tips were then hydrolyzed in $1 \mathrm{~N} \mathrm{HCl}$ at $60{ }^{\circ} \mathrm{C}$ for $6-7$ minutes. After hydrolysis, the root tips were thoroughly washed with water several times and then stained with feulgen stain. When staining was completed, which took 45-60 minutes, the root-tips were transferred to clean slides and the dark stained tips containing the meristem were separated from the rest of the roots. Squash preparations were produced in $45 \%$ acetic acid.

\subsubsection{Scoring of Slides}

In the $V$. faba chromosome aberration assay, slides were scored for chromatid and chromosome aberrations only in metaphase. Five hundred metaphases per root-tip were screened to a total of 2,500 metaphases for each treatment and control to obtain the total number of chromosomal aberrations. The mitotic indices were obtained by counting the number of mitotic cells in 1,000 cells/root-tip to a total of 5,000 cells/treatment and control using an Olympus microscope. The mitotic index was calculated as the ratio of the number of dividing cells to the total number of cells, multiplied by 100 . The aberrations scored were chromatid breaks, isochromatid breaks, chromatid gaps, isochromatid gaps dicentrics, rings and lagging chromosomes.

\subsubsection{Micronucleus Test}

The procedure by Ma [32] was followed with slight modifications for this study. Seeds of $V$. faba were removed from storage and cultured at $28{ }^{\circ} \mathrm{C}$ with distilled water. Seedlings with lateral roots of $V$. faba at about $1-2 \mathrm{~cm}$ in length were collected for this experiment. The lateral roots were treated with four different concentrations $(12.5,25,50$ and $100 \mathrm{mg} / \mathrm{L})$ and a control for $6 \mathrm{~h}$ at $28{ }^{\circ} \mathrm{C}$, they were then transferred into distilled water for $44 \mathrm{~h}$ recovery time. The root tips were cut and fixed in a mixture of methanol and acetic acid $(3: 1, \mathrm{v} / \mathrm{v})$. Before being squashed under a cover slip, the samples were hydrolyzed with $1 \mathrm{~N} \mathrm{HCL}$ at $70{ }^{\circ} \mathrm{C}$ for 7-8 min, stained with feulgen reagent for $2 \mathrm{~h}$, and slides were made permanent. A total of 300 cells were analyzed, which were isolated from 3 different root tips (300 cells per root tip) for each sample. Micronuclei which localized inside the cell wall and in the cytoplasmic area surrounding the main nucleus with a diameter not exceeding one-third of the main nucleus were counted.

\subsubsection{Statistical Analysis}

Statistical analysis was performed with SAS 9.1 software for Windows XP. Data was presented as Means \pm SDs. One-way analysis of variance (ANOVA) with p-values less than 0.05 were considered as statistically significant. 


\section{Results}

\subsection{Nanomaterial Characterization}

Nanoparticles were characterized by TEM with respect to morphology, diameter, tendency of aggregation and cellular distribution. AgNPs were mainly spherical shaped (Figure 1). Observing 300 particles, a mean longitudinal diameter of $63 \pm 41 \mathrm{~nm}($ mean $\pm \mathrm{SE}$ ) and a mean lateral diameter of $36 \pm 21 \mathrm{~nm}$ (mean $\pm \mathrm{SE}$ ) could be measured. Hence, particle sizes matched the declarations of their commercial supplier $(60 \mathrm{~nm})$. The uptake of Ag NPs by the $V$. faba meristematic root tip cells is characterized by histochemical method (feulgen staining) and viewed under BXI-40 Olympus microscope $(1,000 \times)$ is shown in Figure 2. The release of $\mathrm{Ag}^{+}$ions is demonstrated in Table 1 .

Figure 2. A histochemical stained (feulgen Stain) meristematic root-tip cell of Vicia faba showing silver nanoparticle inside viewed under BXI-40 Olympus Microscope $(1,000 \times)$, $\mathrm{mc}=$ meristematic cell.

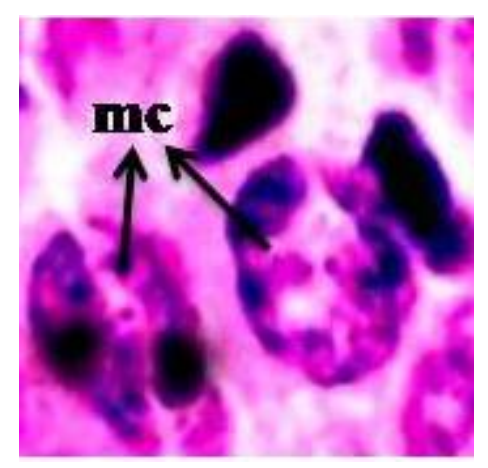

Table 1. Mean release of $\mathrm{Ag}^{+}$ions $(\mathrm{mg} / \mathrm{L})$ to the DI-water: $\mathrm{n}=$ not measurable.

\begin{tabular}{ccc}
\hline $\begin{array}{c}\text { Concentration } \\
(\mathbf{m g} / \mathbf{L})\end{array}$ & Exposure to $\mathbf{A g}$ & Release of $\mathbf{A g}^{+}$ion: \\
\hline Control & $\mathrm{n}$ & $\mathrm{n}$ \\
12.5 & 1.2 & 1.2 \\
25 & 30.4 & 49.2 \\
50 & 60.5 & 121.8 \\
100 & 228.6 & 403.9 \\
\hline
\end{tabular}

To understand the state of dispersion of the particles when placed into deionized water (DI-water), the AgNPs sample was analyzed by dynamic light scattering (DLS). The results from DLS showed agglomeration of Ag-NPs more than its primary size, and the zeta potential value of AgNPs was shown to be $-33.2 \mathrm{mV}$. A solution is considered stable if the zeta potential value is more negative than $-30 \mathrm{mV}$ or more positive than $+30 \mathrm{mV}$.

\subsection{Mitotic Index}

The mitotic index was used to determine the rate of cell division. The slides prepared for the assessment of chromosomal aberrations were used for calculating the mitotic index. It was found 
that the mitotic index significantly decreased as the Ag-NPs doses increased. Mitotic indices of $13.2 \pm 3.98 \%, 9.48 \pm 1.86 \%, 6.8 \pm 1.57 \%, 5.42 \pm 1.36 \%$, and $3.56 \pm 0.36 \%$ were recorded for $0,12.5$, 25, 50 and $100 \mathrm{mg} / \mathrm{L}$ of Ag-NPs respectively (Figure 3).

\subsection{Chromosomal Aberrations}

The metaphase analysis of $V$. faba root-tips revealed various types of chromosomal aberrations, which consisted of chromatid and isochromatid types of gaps, breaks, and fragments. A quantitative assessment of the distribution of breaks and gaps revealed that the distal regions of the chromosomes were more vulnerable to the effects of AgNPs. The results of the chromosomal aberration assay after treatment with AgNPs are summarized in Figure 4. The frequency of chromosomal aberrations (CA) also increased with increasing doses of AgNPs, and statistically significant differences $(p<0.05)$ from the control were observed. The mean percentages of the induced CAs were $4.2 \pm 0.97 \%, 8.8 \pm 0.95 \%$, $13.6 \pm 0.72 \%, 19.2 \pm 1.58 \%, 39.7 \pm 1.43 \%$ for $0,12.5,25,50,100 \mathrm{mg} / \mathrm{L}$ of AgNPs respectively. Representative aberrations are given in Figure 5(A,B).

Figure 3. Effect of silver nanoparticles on the mitotic index in root-tip meristem of Vicia faba. Each experiment was done in triplicate. Data represents mean \pm SD. Statistical significance $(\mathrm{p}<0.05)$ is depicted as $(*)$.

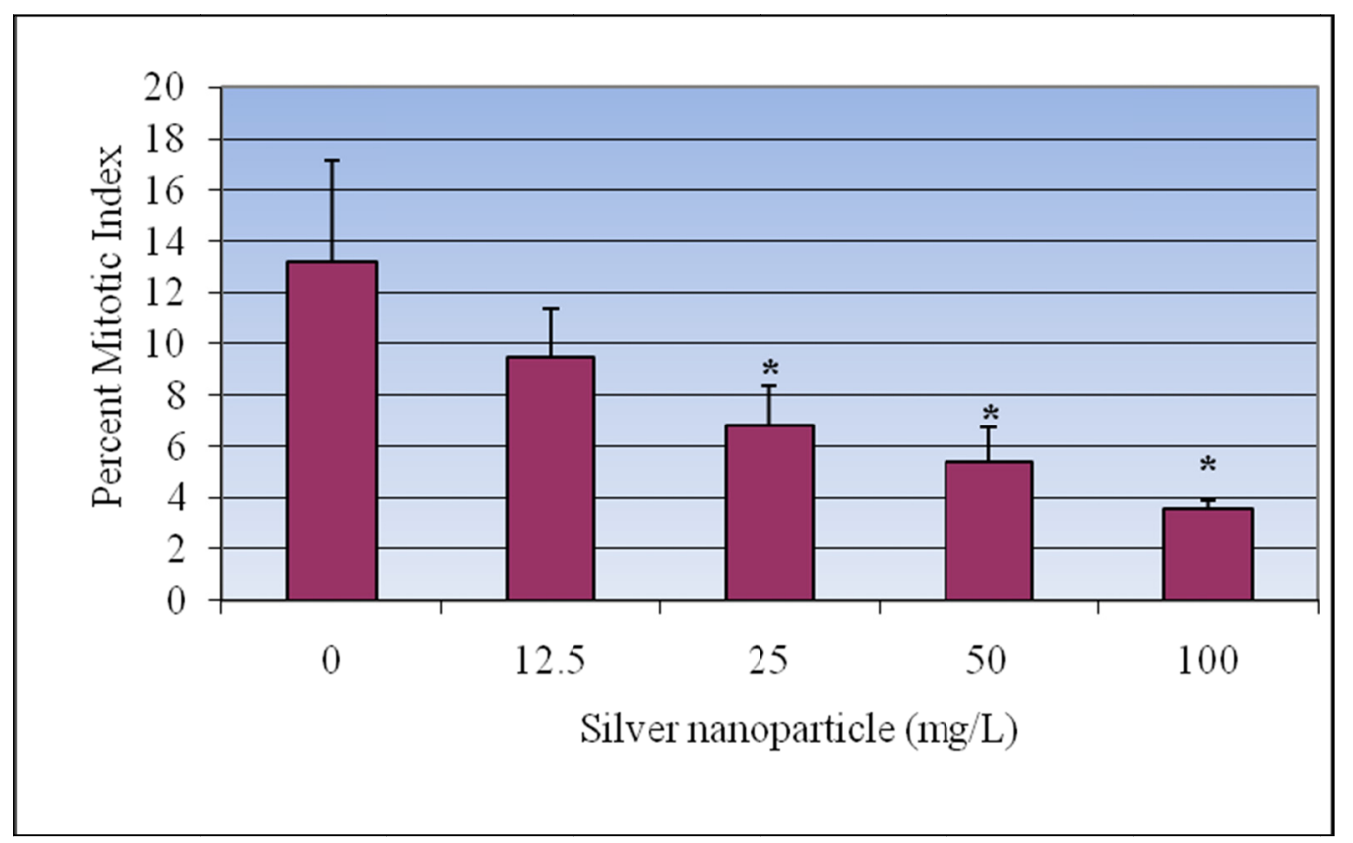

\subsection{Micronucleus Assay}

The results of the micronucleus assay of $V$. faba root-tip exposed to silver nanoparticles are summarized in Figures 6 and 7. The frequency of micronuclei induction was dose-dependent and statistically significant differences $(\mathrm{p}<0.05)$ from the control were observed. The frequencies of micronucleated cells were $5.86 \pm 0.66,8.87 \pm 0.40,14.06 \pm 0.96,16.06 \pm 0.98,18.4 \pm 0.75$ for $0,12.5$, $25,50,100 \mathrm{mg} / \mathrm{L}$ of AgNPs respectively. 
Figure 4. Effect of silver nanoparticles on the frequency of chromosomal aberrations in root-tip meristem of Vicia faba. Each experiment was done in triplicate. Data represents mean \pm SD. Statistical significance $(p<0.05)$ is depicted as $(*)$.

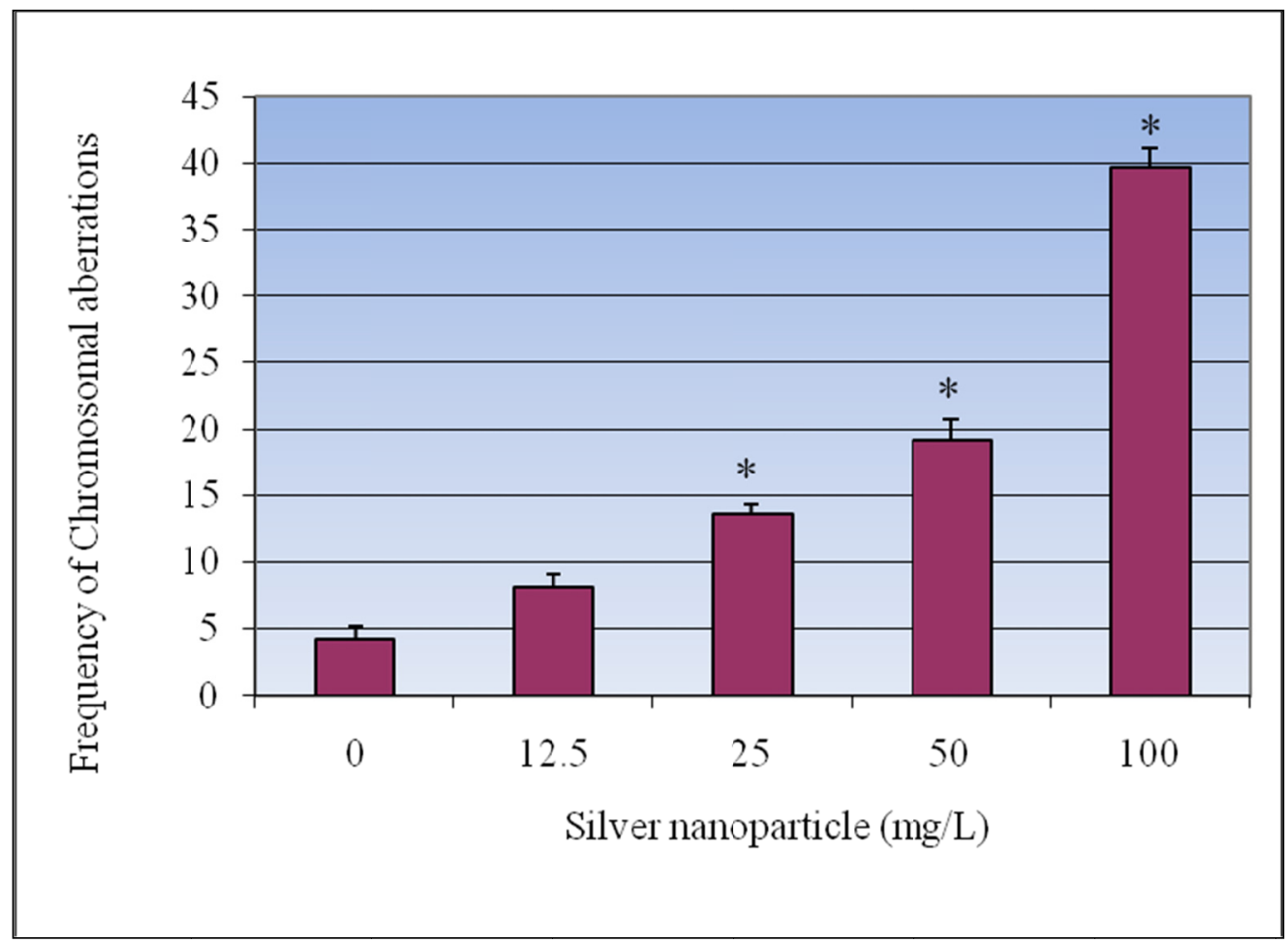

Figure 5. Representative images of metaphase chromosomes in root-tip meristem of Vicia faba. $\mathrm{A}=$ Normal chromosomes, $\mathrm{B}=$ break, $\mathrm{C}=\mathrm{Gap}, \mathrm{D}=$ deletion.
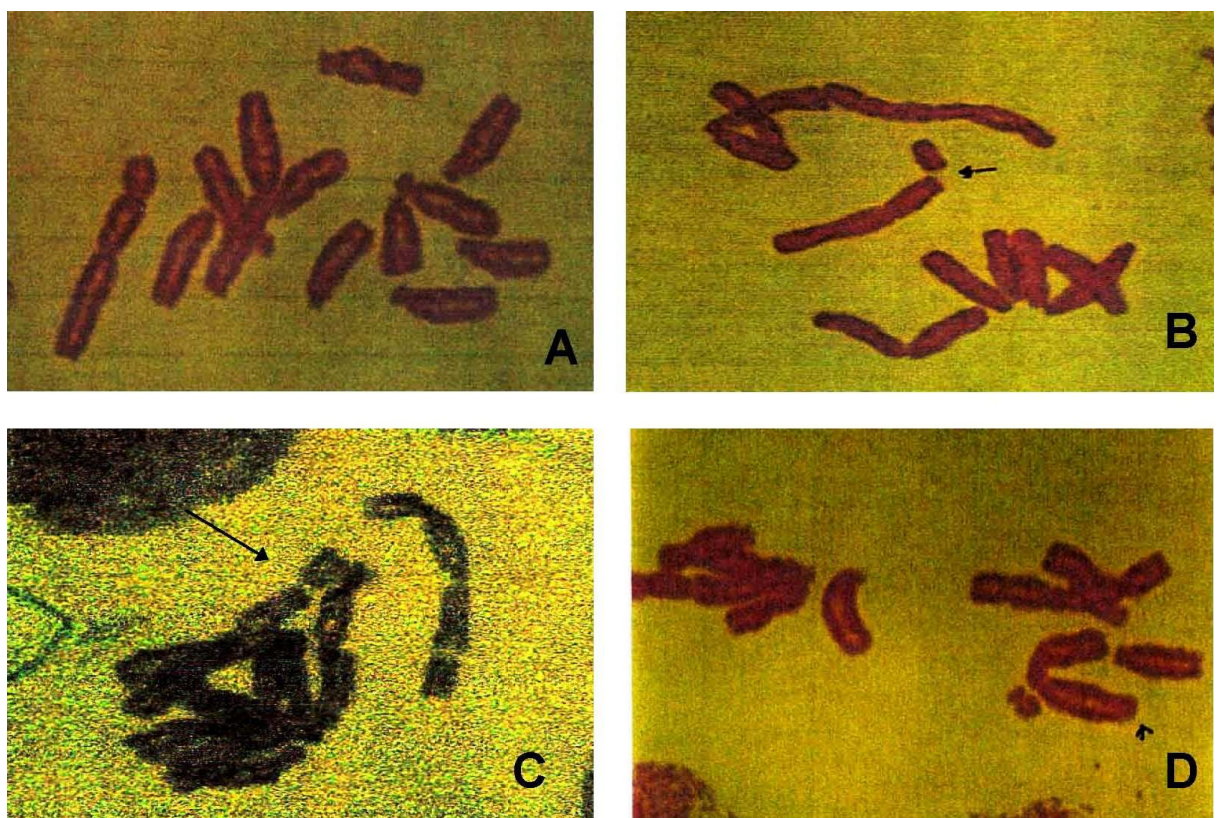
Figure 6. Effect of silver nanoparticles on the frequency of micronucleus induction in root-tip meristem of Vicia faba. Each experiment was done in triplicate. Data represents mean \pm SD. Statistical significance $(\mathrm{p}<0.05)$ is depicted as $(*)$.

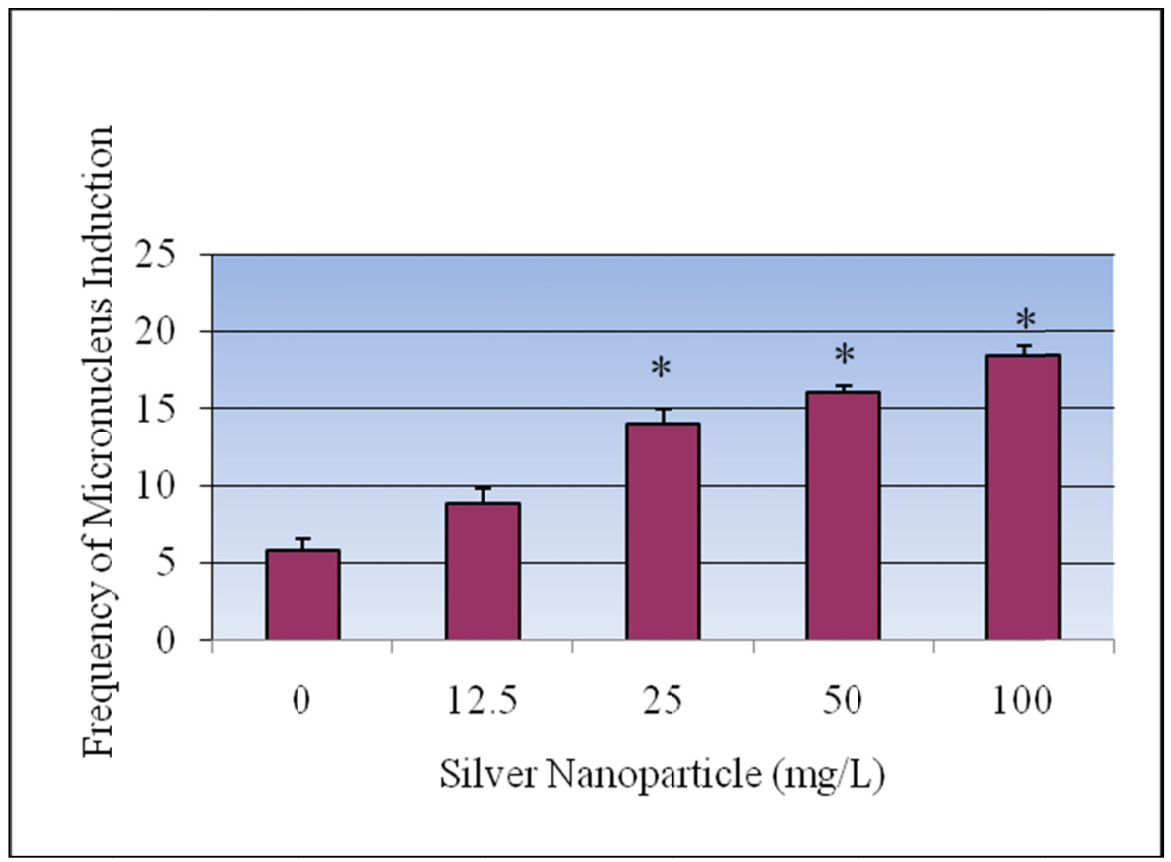

Figure 7. Representative images of micronuclei formation in the root-tip meristem of Vicia faba.

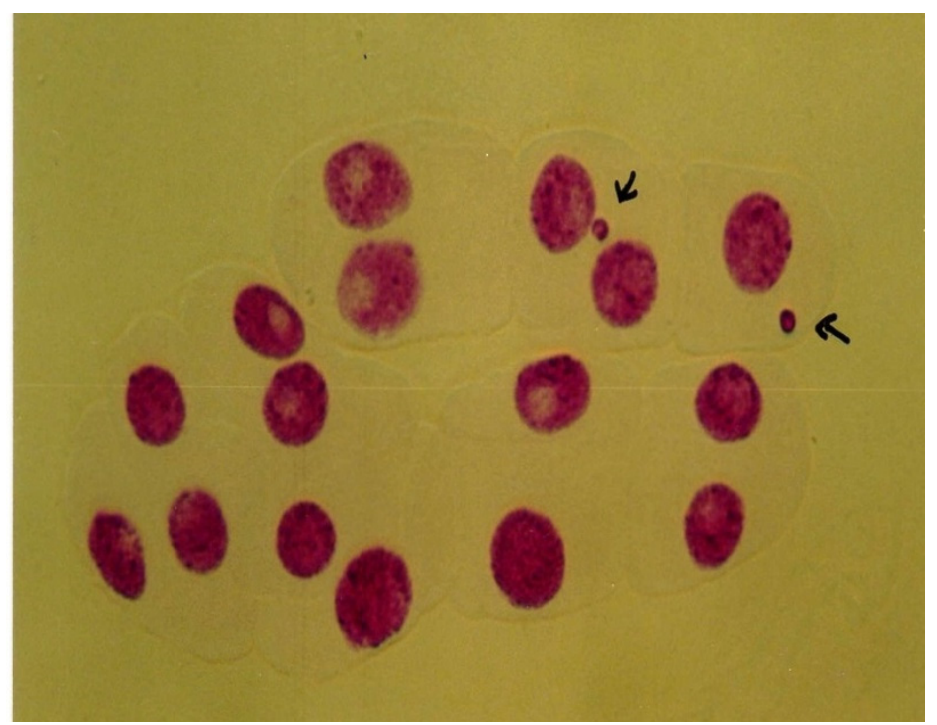

\section{Discussion}

Nanomaterials and nanoparticles have received considerable attention recently due to their unique properties and applications in diverse biotechnology and life science assays. Despite the rapid progress and early acceptance of nanobiotechnology, the potential for adverse effects in humans, non-humans biota and the ecosystems are yet to be thoroughly established. However, the environmental impact of nanomaterial is expected to increase substantially in the future.

In the present investigation, we studied the clastogenic/genotoxic effects of AgNPs in $V$. faba root-tips using mitotic index (MI), structural chromosomal aberrations (CA) and micronuclei induction 
$(\mathrm{MN})$ as the toxicological endpoints. We have noted a decrease in the mean mitotic index values in silver nanoparticle-exposed root-tips as compared to the controls. This could be due to a slower progression of cells from S (DNA synthesis) phase to $M$ (mitosis) phase of the cell cycle as a result of AgNP exposure. It has been suggested that the cytotoxicity level can be determined by the decreased rate of the mitotic index [35]. Although it is most likely that this impairment in cell cycle progression is associated with silver nanoparticles toxicity, further experiments are needed to elucidate the biochemical mechanisms involved. At present, there are no published studies assessing the effect of silver nanoparticles on mitotic index in biological systems. As the mitotic index represents the number of dividing cells it accounts for the growth, and any decrease in mitotic index leads to the reduced growth. The reduction in mitotic index may be caused by the effect of the AgNP/test chemical on the microtubule [36,37].

Different types of structural chromosomal aberrations were observed with different concentrations of silver nanoparticle suspensions. The increase in the induction of structural chromosomal aberrations was found to be statistically significant in exposed root-tips compared to control. Out of all types of aberrations, chromatid breaks, isochromatid breaks, acentric fragments, minutes, translocations and gaps were the predominant forms of CA observed. These results are in agreement with the reports of $[19,38]$. Increases in percentage of aberrations in root meristems indicates genotoxic effects of test chemicals [35]. Number of factors can be contributing to the increased chromosomal aberrations. The most important one is due to the interference of chemicals during DNA repair. Different types of chromosomal aberrations by the chemicals/nanoparticles represent their clastogenicity. The chromosome gaps which involve only the loss of chromatin may be due to the loss of protein part of the chromosome [39]. The chromatid breaks, which represent the DNA double strand breaks that may not have undergone the G2 repair. Any such irreversible DNA damages will lead to the chromosomal aberrations. Irreversible DNA damage would be produced whenever the trapped cleavable complex collides with a replication fork, independently of whether it is euchromatic or heterochromatic regions of the chromosomes that are being replicate [40]. Root tips frequently used for cytogenetic studies in the past five decades were from Allium cepa and Vicia faba [31,33] which are excellent materials for clastogenicity studies of physical and chemical agents.

Li et al. [41] and Chen et al. [42], while working with mammalian cell lines, demonstrated that the nanoparticles penetrated subcellular structures such as the mitochondria and nucleus causing uncoupling of respiration and increased oxidative stress. Tetramethylammonium hydroxide (TMA-OH) coated magnetic nanoparticles of ferrofluid induced chromosomal aberrations in the root meristem cells of Zea mays according to Racuciu et al. [43].

The results from this study showed that there was a statistically significant difference in the frequencies of MN induction in the $V$. faba root-tips exposed to AgNP when compared to control. Similar results were reported in A. cepa root-tips exposed to $\mathrm{ZnO}$ nanoparticles [38] and AgNP [44], showing an increase in the frequency of $\mathrm{MN}$ induction in a dose-dependent manner. Micronucleus formation is the result of acentric fragments or laggards being excluded from the nucleus proper during mitosis [32]. The increase in micronuclei also supports that the test chemicals are clastogenic and are capable of producing different types of chromosomal aberrations. Several hypotheses can be suggested to account for the clastogenic/genotoxic effects of silver nanoparticles, including the formation of adduct and/or damage at the level of DNA or chromosomes. DNA damaging agents have the potential 
to cause genomic instability, which is a predisposing factor in carcinogenesis. Hence, careful monitoring and further characterization of their systemic toxicity, genotoxicity and carcinogenicity is also essential.

\section{Conclusions}

Silver nanoparticles might penetrate plant systems and may interfere with intracellular components, impairing the stages of the cell division. In the present study a dose-dependent decrease in the MI was observed in the exposed group compare to control. There was an increase in the frequencies of CA and $\mathrm{MN}$ in root-tips of $V$. faba. Plant species are widely used for monitoring air pollution and for screening environmental chemicals for their genotoxic effects. The growing public debate on the toxicity and environmental impact of exposures to nanoparticles has not yet thoroughly established. Therefore it is imperative to determine a relatively inexpensive and commonly used short-term plant assay for in situ evaluation of the biological hazards of nanoparticles in the environment. The $V$. faba root tip chromosomal aberration assay is an established plant bioassay by IPCS to study such effects.

\section{Acknowledgement}

This research was supported by grants from National Institutes of Health (NIH)-SEPA (Grant No. RR020405-02) and NIH-RCMI Center for Environmental Health (Grant No. G12RR013459-14) at Jackson State University.

\section{References}

1. Lam, C.W.; James, J.T.; McCluskey, R.; Hunter, R.L. Pulmonary toxicity of single-wall carbon nanotubes in mice 7 and 90 days after intratracheal instillation. Toxicol. Sci. 2004, 77, 126-134.

2. Hackenberg, S.; Scherzed, A.; Kessler, M.; Hummel, S.; Technau, A.; Froelich, K.; Ginzkey, C.; Koehler, C.; Hagen R, Kleinsasser, N. Silver nanoparticles: Evaluation of DNA damage, toxicity and functional impairment in human mesenchymal stem cells. Toxicol. Lett. 2011, 201, 27-33.

3. Oberdörster, G. Effects of Ultrafine Particles in the Lung and Potential Relevance to Environmental Particles. In Aerosol Inhalation; Marijnissen, J.M.C., Gradon, L., Eds.; Kluwer Academic: Dordrecht, The Netherland, 1996; p. 165.

4. Arora, S.; Jain, J.; Rajwade, J.; Paknikar, K. Cellular responses induced by silver nanoparticles: In vitro studies. Toxicol. Lett. 2009, 179, 93-100.

5. Brunner, T.J.; Wick, P.; Manser, P.; Spohn, P.; Grass, R.N.; Limbach, L.K.; Bruinink, A.; Stark, W.J. In vitro cytotoxicity of oxide nanoparticles: Comparison to asbestos, silica, and the effect of particle solubility. Environ. Sci. Technol. 2006, 40, 4374-4381.

6. Hussain, S.M.; Hess, K.L.; Gearhart, J.M.; Geiss, K.T.; Schlager, J.J. In vitro toxicity of nanoparticles in BRL 3A rat liver cells. Toxicol. In Vitro 2005, 19, 975-983.

7. Jia, G.; Wang, H.; Yan, L.; Wang, X.; Pei, R.; Yan, T.; Zhao, Y.; Guo, X. Cytotoxicity of carbon nanomaterials: Single-wall nanotube, multi-wall nanotube, and fullerene. Environ. Sci. Technol. 2005, 39, 1378-1383. 
8. Lam, C.W.; James, J.T.; McCluskey, R.; Arepalli, S.; Hunter, R.L. A review of carbon nanotube toxicity and assessment of potential and environmental health risks. Crit. Rev. Toxicol. 2006, 36, 189-217.

9. Patlolla, A.; Patlolla, B.; Tchounwou, P. Evaluation of cell viability, DNA damage, and cell death in normal human dermal fibroblast cells induced by functionalized multiwalled carbon nanotube. Mol. Cell Biochem. 2010, 338, 225-232.

10. Patlolla, A.K.; Hussain, S.M.; Schlager, J.J.; Patlolla, S.; Tchounwou, P.B. Comparative study of the clastogenicity of functionalized and non-functionalized multi-walled carbon nanotubes in bone marrow cells of Swiss-Webster mice. Environ. Toxiciol. 2010, 25, 608-621.

11. Soto, K.F.; Carrasco, A.; Powell, T.G.; Garza, K.M.; Murr, L.E. Comparative in vitro cytotoxicity assessment of some manufactured nanoparticulate materials characterized by transmission electron microscopy. J. Nanopart. Res. 2005, 7, 145-169.

12. Kim, Y.S.; Kim, J.S.; Cho, H.S.; Rha, D.S.; Park, J.D.; Choi, B.S.; Lim, R.; Chang, H.K.; Chung, Y.H.; Kwon, I.H.; Jeong, J.; Han, B.S.; Yu, I.J. Twenty-eight day oral toxicity, genotoxicity, and gender-related tissue distribution of silver nanoparticles in Sprague-Dawley rats. Inhal. Toxicol. 2008, 20, 575-583.

13. AshaRani, P.V.; Mun, G.L.K.; Hande, M.P.; Valiyaveettil, S. Cytotoxicity and genotoxicity of silver nanoparticles in human cells. ACS Nano 2009, 3, 279-290.

14. Rahman, M.F.; Wang, J.; Patterson, T.A.; Saini, U.T.; Robinson, B.L.; Newport, G.D.; Murdock, R.C.; Schlager, J.J.; Hussain, S.M.; Ali, S.F. Expression of genes related to oxidative stress in mouse brain after exposure to silver-25 nanoparticles. Toxicol. Lett. 2009, 187, 15-21.

15. Carlson, C.; Hussain, S.M.; Schrand, A.M.; Brandich-Stolle, L.K.; Hess, K.L.; Jones, R.L.; Schlager, J.J. Unique cellular interaction of silver nanoparticles: Size-dependent generation of reactive oxygen species. J. Phys. Chem. 2008, 112, 13608-13619.

16. Vinardell, M.P. In vitro cytotoxicity of nanoparticles in mammalian germ-line stem cell. Toxicol. Sci. 2005, 88, 285-286.

17. Kim, S.; Choi, E.J.; Choi, J.; Chung, K.; Park, K.; Yi, J. Oxidative stress-dependent toxicity of silver nanoparticles in human hepatoma cells. Toxicol. In Vitro 2009, 23, 1076-1084.

18. Zanette, C.; Pelin, M.; Crosera, M.; Adami, G.; Bovenzi, M.; Larese, F.F.; Florio, C. Silver nanoparticles exert a long-lasting antiproliferative effect on human keratinocyte HaCaT cell line Toxicol. In Vitro 2011, 25, 1053-1060.

19. Mamta, K.; Mukherjee, A.; Chandrasekaran, N. Genotoxicity of silver nanoparticles in Allium cepa. Sci. Total Environ. 2009, 407, 5243-5246.

20. Oberdörster, E. Manufactured nanomaterials (fullerenes, C60) induce oxidative stress in the brain of juvenile Largemouth Bass. Environ. Health Perspect. 2004, 112, 1058-1062.

21. Ahmed, M.; Posgai, R.; Gorey, T.J.; Nielsen, M.; Hussain, S.M.; Rowe, J.J. Silver nanoparticles induced heat shock protein 70, oxidative stress and apoptosis in Drosophila melanogaster. Toxicol. Appl. Pharmacol. 2010, 242, 263-269.

22. USEPA. Nanotechnology White Paper; Science Policy Council, USEPA: Washington, DC, USA, 2007. 
23. Lu, C.M.; Zhang, C.Y.; Wen, J.Q; Wu, G.R.; Tao, M.X. Research of the effect of nanometer materials on germination and growth enhancement of Glycine max and its mechanism. Soybean Sci. 2002, 21, 168-172.

24. Hong, F.S.; Yang, F.; Liu, C.; Gao, Q.; Wan, Z.G.; Gu, F.G.; Wu, C.; Ma, Z.N.; Zhou, J.; Yang, P. Influences of nano- $\mathrm{TiO}_{2}$ on the chloroplast aging of spinach under light. Biol. Trace Elem. Res. 2005, 104, 249-260.

25. Hong, F.S.; Zhou, J.; Liu, C.; Yang, F.; Wu, C.; Zheng, L.; Yang, P. Effect of nano-TiO ${ }_{2}$ on photochemical reaction of chloroplasts of spinach. Biol. Trace Elem. Res. 2005, 105, 269-279.

26. Yang, L.; Watts, D.J. Particle surface characteristics may play an important role in phytotoxicity of alumina nanoparticles. Toxicol. Lett. 2005, 158, 122-132.

27. Zheng, L.; Hong, F.S.; Lu, S.P.; Liu, C. Effect of nano- $\mathrm{TiO}_{2}$ on strength of naturally aged seeds and growth of spinach. Biol. Trace Elem. Res. 2005, 104, 83-91.

28. Chen, X.; Schluesener, H.J. Nanosilver: A nanoproduct in medical application. Toxicol. Lett. 2008, 176, 1-12.

29. Tripathy, A.; Chandrasekran, N.; Raichur, A.M.; Mukherjee, A. Antibacterial applications of silver nanoparticles synthesized by aqueous extract of Azadirachta indica (Neem) leaves. J. Biomed. Nanotechnol. 2008, 4, 1-6.

30. Luoma, S.N. Silver Anotechnologies and the Environment: Old Problems or New Challenges? The Project of Emerging Nanotechnologies: Washington, DC, USA, 2008.

31. Grant, W.F. Chromosome aberration assays in Allium. A report of the US Environmental Protection Agency gene-Tox Program. Mutat. Res. 1982, 99, 273-291.

32. Ma, T.H.; Xu, Z.; Xu, C.; McConnell, H.; Rabago, E.V.; Arreola, G.A.; Zhang, H. The improved Allium/Vicia root tip micronucleus assay for clastogenicity of environmental pollutants. Mutat. Res. 1995, 334, 185-195.

33. Ma, T.H. Vicia cytogenetic tests for environmental mutagens. A report of the US Environmental Protection Agency Gene-Tox Program, Mutat Res. 1982, 99, 259-271.

34. Kanaya, N.; Gill, B.S.; Grover, I.S.; Murin, A.; Osiecka, R.; Sandhu, S.S.; Andersson, H.C. Vicia faba chromosomal aberration assay. Mutat. Res. 1994, 310, 231-247.

35. Smaka-Kincl, V.; Stegnar, P.; Lovka, M.; Toman, J.M: The evaluation of waste, surface and ground water quality using the Allium test procedure. Mutat. Res. 1996, 368, 171-179.

36. Webster, P.L.; Davidson, D. Changes in the duration of mitotic cycle induced by colchicine and indole-3-yl acetic acid in V. faba roots. J. Exp. Bot. 1969, 20, 671-685.

37. Macleod, R.D. Some effects of 2,4,5-trichlorophenoxy acetic acid on the mitotic cycle of lateral root apical meristems of $V$. faba. Chromosoma 1969, 27, 327-337.

38. Kumari, M.; Khan, S.S.; Pakrashi, S.; Mukherjee, A.; Chandrasekaran, N. Cytogenetic and genotoxic effects of zinc oxide nanoparticles on root cells of Allium cepa.J. Hazard Mater. 2011, 90, 613-621.

39. Topaktas, M.; Renciizogullar, E. Chromosomal aberrations in cultured human lymphocytes treated with Marshal and its effective ingredient Carbosulfan. Mutat. Res. 1993, 319, 103-111. 
40. Kihlman, B.A.; Anderson, H.C. Root-Tips of Vicia faba for the Study of the Induction of Chromosomal Aberrations and Sister-Chromatid Exchanges. In Handbook of Mutagenecity Test Procedures; Kilbey, B.J., Legator, M.S., Nichols, W., Ramel, C., Eds.; Elsevier: Amsterdam, The Netherland, 1984; pp. 531-554.

41. Li, N.; Sioutas, C.; Cho, A.; Schmitz, D.; Mistra, C.; Sempf, J.M. Ultrafine particulate pollutants induce oxidative stress and mitochondrial damage. Environ. Health Perspect. 2003, 111, 455-460.

42. Chen, M.; Von Mickecz, A. Formation of nucleoplasmic protein aggregates impairs nuclear function in response to $\mathrm{SiO}_{2}$ nanoparticles. Exp. Cell Res. 2005, 305, 51-62.

43. Racuciu, M.; Creanga, D.E. TMA-OH coated magnetic nanoparticles internalized in vegetal tissue. Rom. J. Phys. 2007, 52, 367-374.

44. Panda, K.K.; Achary, M.M.; Krishnaveni, R.; Padhi, B.K.; Sarangi, S.N.; Sahu, S.N.; Panda, B.B. In vitro biosynthesis and genotoxicity bioassay of silver nanoparticles using plants. Toxicol. In Vitro 2011, 25, 1097-1105.

(C) 2012 by the authors; licensee MDPI, Basel, Switzerland. This article is an open access article distributed under the terms and conditions of the Creative Commons Attribution license (http://creativecommons.org/licenses/by/3.0/). 